DOI: https://doi.org/10.32839/2304-5809/2021-11-99-35

удК 378.6

Герганов Л.Д., Ярмакі А.Х.

Дунайський інститут

Національного університету «Одеська морська академія»

\title{
ВПРОВАДЖЕННЯ ЦИФРОВИХ ТЕХНОЛОГІЙ В ОСВІТНІЙ ПРОЦЕС ЗАКЛАДУ ВИЩОЇ МОРСЬКОЇ ОСВІТИ
}

\begin{abstract}
Анотація. В даній статі розкрито сутність та основну мету щодо впровадження в освітній процес підготовки майбутніх моряків новітніх комп'ютерних технологій. Авторами було виявлено, що використання платформи Google-Education, a саме Classroom в інформаційно-освітньому середовищі кафедри інженерних дисциплін Дунайського інституту НУ «Одеська морська академія» у підготовці майбутніх інженерів, впливає не лише на якість здобутих знань, а й на подальшу професійну діяльність. Було зазначено, на яких навчальних дисциплінах автори зробили свої наукові висновки, а саме: «Технологія матеріалів і ремонт суднового обладнання», «Опір матеріалів», «Морська інженерна практика», «Нарисна геометрія та комп'ютерна графіка». Схематично було зображено міждисциплінарний зв'язок фрахових дисциплін на кафедральному рівні. У загальній структурі освітньо-професійне середовища розглянуто як поетапний процес фрормування цифрових компетенцій у професійній діяльності майбутнього суднового механіка.
\end{abstract}

Ключові слова: цифрові технології, освітній процес, моряки, інформаційне середовище, навчальні дисципліни.

Gerganov Leonid, Yarmaki Anatolii

Danube Institute of the National University «Odessa Maritime Academy»

\section{INTRODUCTION OF DIGITAL TECHNOLOGIES IN THE EDUCATIONAL PROCESS OF THE INSTITUTION OF HIGHER MARINE EDUCATION}

Summary. The essence and main purpose of the introduction of computer technologies in the educational process of training future sailors were revealed in this article. The authors found that the use of the Google-Education platform, namely Classroom in the information and educational environment of the Department of Engineering Disciplines of the Danube Institute National University «Odessa Maritime Academy» in the training of future engineers, affects not only the quality of knowledge but also further professional activity. The research was conducted in professional disciplines, namely «Technology of Materials and Repair of Ship Equipment», «Strength of Materials», «Marine Engineering Practice», «Descriptive Geometry and Computer Graphics». This scientific research considers such concepts as information and educational environment and professional image, it is determined what skills future marine engineers should have. Google Classroom shows the process of manufacturing parts of marine internal combustion engines on a lathe, the structure and principles of marine internal combustion engines, main engines, measuring equipment using photo and video resources from a dry cargo ship. The interdisciplinary connection of professional disciplines at the departmental level was schematically depicted. In the general structure the educational-professional environment is considered as a step-bystep process of formation of digital competences in professional activity of the future ship mechanic. Given the significant development and implementation of ICT technologies in the practice of vocational education and in the equipment of modern ships, there is a need to reconsider the main approaches to the formation of professional competence of future bachelors. It should also be noted that during the Covid-19 epidemic, which forces Ukrainian higher education institutions to make innovative decisions for a limited time and introduce blended learning using different platforms, resources and social networks, this approach is especially relevant.

Keywords: digital technologies, educational process, sailors, information environment, academic disciplines.

$\Pi$ остановка проблеми. Для соціальноекономічного розвитку України необхідні умови, які пов'язані з самореалізацією людини як у профресійній діяльності, так і повсякденному житті. При такому підході майбутні фрахівці зможуть ставити й розв'язувати складні виробничі питання, які спрямовані на вирішення сучасних проблем взаємозв' язку профресійної освіти та ринку праці. Все це залежить від їх не тільки профресійної підготовки, але й професійного іміджу: інтелектуальних здібностей, здатності повнощінно взаємодіяти з суспільством, знайти свое місце у колективі, вільно реалізувати свої профресійні і життеві плани й цілі, відповідати за результати своїх дій. Прийнята державна програма «Про затвердження Морської доктрини України на період до 2035 року», з огляду на швидкий розвиток міжрегіональної транспортної, торговельної та інформаційної інфрраструктури констатує, що сучасний розвиток транспортного комплексу країни повинен враховувати не тільки необхідність адаптащії до европейських стандартів технічних умов, принципів управління тощо, а й те, що інновації та втілення високих технологій мають вирішальне значення під час формування нової моделі майбутнього фрахівця та подальшого розвитку управління транспортно-дорожнім комплексом У країни [3].

Аналіз останніх досліджень i публікацій. Результати досліджень українських i зарубіжних науковців 3 проблем розвитку та впровадження інформаційно-комунікаційних технологій у процес продесійної підготовки розкрито в працях В. Бикова, О. Бурова, А. Гуржія, Т. Коваль, О. Колгатина, А. Коломіець, В. Кременя, В. Кухаренка, Н. Морзе, О. Співаковського, О. Спіріна, Ю. Триуса, С. Яшанова та ін. Вони підтверджують, що через досить короткий термін 
використання новітніх технологій на виробництві кардинально змінить виробничі процеси, а нові технології приведуть до розширення видів діяльності фахівця та потребуватимуть його виробничої мобільності. Різні аспекти впровадження циоровізації в освітній простір стали предметом дослідження зарубіжних вчених (К. Бассет, К. Гере, Г. Грибер, М. Деузе, Г. Крибер і Р. Мартін, Л. Манович, Дж. Стоммел, М. Хенд і вітчизняних (Д. Галкін, М. Жалдак, М. Лещенко, П. Матюшко, О. Овчарук). Різноманітні аспекти проблеми профресійної підготовки фрахівців морського профрілю, які пов'язані з застосуванням IКT, обгрунтовувалися вітчизняними вченими О. Дягеловою, В. Захарченко, С. Козаком, М. Кулаковою, А. Погодаєвою, І. Сокола, В. Тітяевим, К. Ткаченко та ін.

Зокрема, К. Ткаченко [4] досліджує систему підготовки фрахівців водного та морського транспорту з широким використанням IКТ при впроваджені ситуаційно-пошукових методів для вирішення завдань аварійних і небезпечних ситуащій на суднах.

Метою статті $е$ розгляд результатів дослідження 3 форомування продесійно-освітнього середовища у рамках кафедри 3 викладання інженерних дисциплін за допомогою цифрових носіїв та професійного іміджу майбутніх суднових механіків з провадженням у освітню діяльність діджиталізації. Під цифровою трансформацією ми розуміємо процес впровадження у освітню діяльність діджиталізащії, що значно спрощуе доступ до необхідної інформації. Щодо поняття «діджиталізація», то науковці тлумачать їі як способи приведення будь-якого різновиду інформації в цифрову форму з використанням цифрових технологій [2].

Виклад основного матеріалу. Цифровізація освіти сьогодні є головним трендом розвитку освітніх систем майже в усіх країнах світу й охоплюе всі рівні - від початкової освіти до магістрів та докторів наук. Стрімке розповсюдження «цифррових» технологій робить цифррові компетенщії громадян, за думкою вчених та фрахівщів з IT-технологій $є$ ключовими серед інших навичок. Так, «цифровізація» та багатоплатформість $є$ головними трендами сьогодення на загальному ринку праці, особливо за умови карантину.

Підготовка для морської галузі конкурентоспроможного морського офіцера потребуе від навчального закладу освіти продовжити до- слідження з сучасних підходів до фрормування у нього цифрових компетенцій. При цьому професорсько - викладацький склад повинен не тільки володіти, але й сприяти впровадженню цифрових технологій у практичну діяльність майбутньої продесії курсантів. На жаль, частіше буває так, що навики володіння цифровими компетенціями викладачами не достатньо для впровадження в освітній процес. За нашою думкою, для подолання цієї проблеми доцільно у навчальному закладі та створити освітньо-професійне середовище за спрямуванням, яке надає можливості об'єднати зусилля по формуванню цифррової компетентності як викладацького складу, так і курсантів. Створення такого середовища має відповідати як загальнодидактичним, так і специфічним принципам, а саме: визначення цілеспрямованості освіти суб'єкта пізнання; системності отримання професійних знань, науковості у даній галузі пізнання; доступності у засвоєнні навчального матеріалу та його орієнтація на самоосвіту, саморозвиток та найголовніший - на особистісне спрямування. За специфічними принципами: самовизначення суб'єкта пізнання 3 профресійного напряму; соціалізації особистості у майбутній професійній діяльності, самовизнання своєї конкурентноспроможності, індивідуалізащія побудови профресійної кар'єри та освітньої траєкторії.

Таким чином, було прийнято рішення розробити освітне - професійне середовище з фрахових дисциплін з використанням елементів цифрових технологій таких як «Морська інженерна практика», «Технологія матеріалів та ремонт суднового обладнання», «Опір матеріалів» та «Нарисна геометрія та комп'ютерна графріка» (див. рис. 1).

Важливим елементом у нашому дослідженні $\epsilon$ міждисциплінарний зв'язок в освітньому індрормаційному середовищі. Доречним для іміджетворного потенціалу майбутніх суднових механіків є зв'язок саме фрахових дисциплін та їх вплив на якісне засвоєння спеціальних дисциплін та форормування практичних навичок в процесі.

Іншими словами, вміння працювати із «цифровими» технологіями поступово стає постійним та необхідним для більшості морських спеціалізацій. Взагалі кількість професій, спеціальностей та робочих місць в Україні, що вимагають принаймні базового розуміння інформаційних та комунікаційних технологій, стрімко збільшуеться. Унікальність оволодіння цифровими нави-

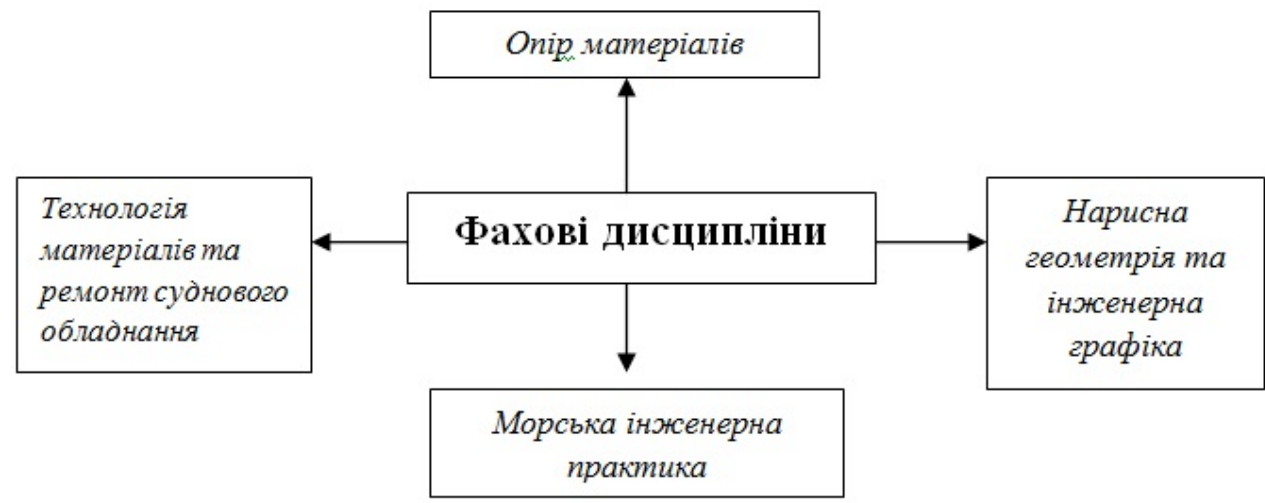

Рис. 1. Міждисциплінарний зв'язок фахових дисциплін на кафедральному рівні 
чками полягає в тому, що завдяки їм особистість має можливість більш едективніше набувати компетенцій в багатьох сфрерах діяльності. Національна освітня система України повинна просуватися вперед із сучасною програмою проdресійного навчання загальним та продесійним діджитал компетенціям та навичкам як ключовим компонентам «цифрової» економіки.

Для вирішення поставленої проблеми, нами, у рамках розробленого освітньо-профресійного середовища, було проведено соціолого-педагогічне дослідження, у якому брало участь 100 респондентів, курсантів Дунайського інституту Нащіонального університету «Одеська морська академія». Упродовж дослідження проводилися контрольні зрізи, що дали змогу діагностувати рівень розвиненості цифрової компетентності курсантів.

Результати контрольних зрізів показали, що 340 курсантів другого курсу - 20 чоловік добре орієнтуються в додатках смартфону, однак низькими виявилися результати володіння мають хороші навички роботи стаціонарним комп'ютером - лише 15 курсантів; і тільки 5 курсантів вміють працювати 3 інтерактивною дошкою. А от результати першого курсу виявилися достатньо гіршими (з 60 респондентів лише 40 мають знання до використання освітніх додатків смартфонів, 15 - стаціонарним комп'ютером, та 5 курсантів мають достатні знання для праці 3 інтерактивною дошкою).

Дане дослідження було проведено для визначення рівня діджитал компетенцій курсантів 3 використанням платформи Google Education у навчальному процесі при дистанційному навчанні.

Висновки. Сьогодні, враховуючи специфріку роботи майбутніх фрахівців на автоматизованих суднах у скорочених багатонаціональних екіпажах морських суден [1], від вахтового механіка вимагається повне розуміння устрою, принципу роботи та правил експлуатації усіх суднових допоміжних механізмів та систем, зокрема даної установки судна. Для досягнення такої мети у навчальному процесі викладачу необхідно використовувати не тільки демонстраційні плакати, але й навчальні відеоматеріали з теоретичної частини курсу термодинаміки та комп'ютерного симулятора 3 даної установки, однак найбільш важливим у цьому питанні, є власний практичний досвід експлуатації даної установки.

\section{Список літератури:}

1. Ковнір О. І. Роль компетентнісного підходу у формуванні політичної культури майбутнього офіцера морського фрлоту. Засоби навчальної та науково-дослідної роботи. 2012. № 38. С. 41-48.

2. Куприна К. А. Диджитализация: понятие, предпосылки возникновения и сферы применения. Вестник научных конфберенций. 2016. № 5-5(9). С. 259-262.

3. Морська доктрина України на період до 2035 року : Постанова Кабінету Міністрів України від 07 жовтня 2009 року №1307. URL: https://zakon.rada.gov.ua/laws/show/1108-2018-\%D0\%BF\#n2 (дата звернення: 22.11.2021).

4. Ткаченко К. Дослідження проблем системи підготовки фрахівців водного та морського транспорту. Еконолічний аналіз. 2012. Вип. 10. Ч. 2. С. 71-74.

\section{References:}

1. Kovnir O. (2012) Rol kompetentnisnoho pidkhodu u formuvanni politychnoi kultury maibutnoho ofitsera morskoho flotu [The role of the competence approach in shaping the political culture of the future naval officer]. Zasoby navchalnoi ta naukovo-doslidnoi roboty, vol. 38, pp. 41-48.

2. Kuprina K. (2016) Dydzhytalyzatsyia: poniatye, predposylky voznyknovenyia y sfery prymenenyia [Digitalization: concept, prerequisites and scope]. Vestnyk nauchnykh konferentsyi, vol. 5-5(9), pp. 259-262.

3. Morska doktryna Ukrainy na period do 2035 roku: Postanova Kabinetu Ministriv vid 07 Zhovtnia 2009 roku № 1307 [Marine doctrine for the period till 2035 year. Regulation of the Cabinet of Ministers from 07 October 2009 № 1307]. (n.d.). zakon.rada.gov.ua Retrieved from: https://zakon.rada.gov.ua/laws/show/1108-2018$\% \mathrm{D} 0 \% \mathrm{BF} \# \mathrm{n} 2$ (in Ukrainian)

4. Tkachenko K. (2012) Doslidzhennia problem systemy pidhotovky fakhivtsiv vodnoho ta morskoho transportu [Advancement of the problems of the system and preparation of water and sea transport]. Ekonomichnyi analiz, vol. 10(2), pp. 71-74. 